\title{
Some intertidal and shallow water polychaetes of the Caribbean coast of Costa Rica
}

\author{
Harlan K. Dean ${ }^{1,2}$ \\ 1. Department of Biology, University of Massachusetts- Boston, Boston, Massachusetts 02125-3393, USA; \\ harlan.dean@umb.edu \\ 2. Department of Invertebrates, Museum of Comparative Zoology, Harvard University, 26 Oxford Street, Cambridge, \\ Massachusetts 02138 , USA
}

Received 09-VII-2016. Corrected 06-IX-2016. Accepted 07-X-2016.

\begin{abstract}
The polychaete fauna of the Caribbean coast of Costa Rica has been inadequately characterized with only nine species previously reported. Collections of polychaetes from intertidal coralline rocks and several shallow sub-tidal sites on the Caribbean coast of Costa Rica have been examined and 68 species were identified. Of these, 66 are new records for Costa Rica. Rev. Biol. Trop. 65 (1): 127-152. Epub 2017 March 01.
\end{abstract}

Key words: Annelida, Polychaeta, Caribbean Sea, Costa Rica, marine biodiversity, intertidal.

The Caribbean coast of Costa Rica is shorter $(212 \mathrm{~km})$ when compared with its Pacific Coast $(1254 \mathrm{~km})$ (Cortés \& Wehrtmann, 2009). Much of the Caribbean coast is sandy beaches with some rocky areas and coral reefs in the Southern portion. Sea-grass beds also occur in the lagoons of the coral reefs and consist mainly of Thalassia testidunum with some Syringodium filiformis interspersed (Cortés \& Wehrtmann, 2009). Wehrtmann, Cortés and Echeverría-Sáenz (2009) listed 2321 known species of organisms from this coast with 1264 of these being benthic invertebrates. The most speciose marine invertebrate taxa are molluscs with 712 known species and the arthropods with 287 species.

Dean (2009) listed only five known species of polychaetes from Caribbean Costa Rica and in his review of Caribbean polychaetes Dean (2012) listed six species based upon Böggemann's (2002) tacit recognition of Hemipodia armata (Hartman, 1950) as a separate species from H. pustulata (Friedrich, 1956). In these works, Dean had overlooked the work of Pepe (1985) who had reported an additional three species from the rocky intertidal of Cahuita. Nonetheless, the occurrence of only nine known species of polychaetes indicates that this taxon has been largely neglected in this region.

In this paper materials collected during several trips to the Caribbean coast of Costa Rica funded by Centro de Investigación en Ciencias del Mar y Limnología (CIMAR), University of Costa Rica (UCR), were analyzed. Additional material was also provided by several Costa Rican researchers. Sixty eight species were herein reported and diagnosed with 66 new polychaete species records for Caribbean Costa Rica.

\section{MATERIALS AND METHODS}

Collecting trips to Limón, Cahuita and Manzanillo, Province of Limón, Caribbean of Costa Rica, were undertaken with the aid of J. A. Vargas and J. Cortés of CIMAR in June, 1994, August 2006, August 2009, May and June 2011, and May 2012. Most collections were taken from rocky intertidal regions along 
the Southern Caribbean coast by breaking fossil or living coralline rocks and removing polychaete specimens. Materials were also collected from the root mats of seagrass beds in Parque Nacional Cahuita. Materials were fixed in $95 \%$ alcohol or $10 \%$ formalin/seawater (which was transferred to $80 \%$ alcohol after several days). Material from Puerto Vargas was also collected by Richard Heard, from Moín by $\mathrm{K}$. Rodríguez, and from Mondonguillo by J. Sibaja-Cordero, all in the Province of Limón.

Specimens were identified in the laboratory and later deposited in the Department of
Invertebrates in the Museum of Comparative Zoology, Cambridge, MA (USA) with the exception of specimens of 27 species deposited in the Museum of Zoology, Universidad de Costa Rica (as indicated in the text by Museum of Zoology, Universidad de Costa Rica, numbers (MZUCR)).

\section{RESULTS}

List of species encountered in the present study

Family Amphinomidae Savigny in Lamarck, 1818

Eurythoe complanata (Pallas, 1766)

Hermodice carunculata (Pallas, 1766)

Linopherus canariensis Langerhans, 1881

Family Capitellidae Grube, 1862

Dasybranchus lumbricoides (Grube, 1878)

Family Chaetopteridae Audouin and Milne Edwards, 1833

Mesochaetopterus capensis (McIntosh, 1885)

Family Chrysopetalidae Ehlers, 1864

Bhawania cf. goodei Webster, 1884

Family Cirratulidae Carus, 1863

Timarete punctata (Grube, 1859) species complex

Family Eunicidae Berthold, 1827

Eunice bucciensis (Treadwell, 1921)

Eunice elegans (Verrill, 1900)

Eunice fucata Ehlers, 1887

Eunice goodei Fauchald, 1992

Eunice guanica (Treadwell, 1921)

Eunice longisetis Webster, 1884

Leodice rubra (Grube, 1856)

Lysidice caribensis Carrera-Parra, Fauchald \& Gambi, 2011

Marphysa longula (Ehlers, 1887)

Marphysa veracruzensis de León-González \& Díaz-Castañeda, 2006

Palola siciliensis (Moore, 1904)

Family Flabelligeridae de Saint-Joseph, 1894

Semiodera dubia (Treadwell, 1929)

Semiodera treadwelli Salazar-Vallejo, 2012

Family Glyceridae Grube, 1850

Hemipodia pustatula (Friedrich, 1956)

Family Lumbrineridae Schmarda, 1861

Scoletoma ernsti (Perkins, 1979)

Family Maldanidae Malmgren, 1867

Axiothella sp. 
Family Nereididae Blainville, 1818

Ceratonereis excisa (Grube, 1874)

Ceratoneris irritabilis (Webster, 1879)

Nereis cf grayi Pettibone, 1956

Nereis riisei Grube, 1857

Perinereis sp.

Platynereis dumerilii (Audouin \& Milne-Edwards, 1933)

Family Oenonidae Kinberg, 1865

Arabella multidentata (Ehlers, 1887)

Family Onuphidae Kinberg, 1865

Diopatra cuprea (Bosc, 1802)

Family Opheliidae Malmgren, 1867

Polyophthalmus pictus (Dujardin, 1839)

Family Pilargidae de Saint-Joseph, 1899

Synelmis sotoi Salazar-Vallejo, 2003

Family Polynoidae Malmgren, 1867

Halosydna leukohyba Schmarda, 1861

Harmothoe muiri Salazar-Silva, 2010

Harmothoe polytrichoides Augener, 1922

Hermenia verruculosa Grube, 1857

Lepidonotus lacteus (Ehlers, 1887)

Lepidonotus sublevis Verrill, 1873

Lepidonotus variabilis Webster, 1879

Family Sabellariidae Johnston, 1865

Sabellaria floridensis Hartman, 1944

Family Sabellidae Latreille, 1825

Bispira melanostigma (Schmarda, 1861)

Megalomma perkinsi Tovar-Hernández \& Salazar-Vallejo, 2006

Notaulax nudicollis (Krøyer, 1856)

Notaulax occidentalis (Baird, 1865)

Parasabella jamaicensis (Augener, 1922)

Pseudopotamilla fitzhughi Tovar-Hernández \& Salazar-Vallejo, 2006

Family Sigalionidae Malmgren, 1867

Fimbriosthenelais hobbsi Pettibone, 1971

Family Spionidae Grube, 1850

Prionospio (Prionospio) cf. heterobranchia Moore, 1907

Family Syllidae Grube, 1850

Branchiosyllis lorenae San Martín \& Bone, 1999

Eusyllis lamelligera Marin \& Bebretzky, 1875

Exogone rolani San Martín, 1991

Haplosyllis niphatesicola Lattig \& Martin, 2011

Odontosyllis enopla Verrill, 1900

Odontosyllis guillermoi Fukuda \& Nogueira, 2006

Syllis beneliahuae (Campoy \& Alquezar, 1982)

Syllis broomensis (Hartmann-Schröder, 1979)

Syllis corallicola Verrill, 1900

Syllis garciai (Campoy, 1982)

Syllis lutea (Hartmann-Schroeder, 1960)

Trypanosyllis vittigera Ehlers, 1887 
Family Terebellidae Johnston, 1846

Amphitritides bruneocomata (Ehlers, 1887)

Eupolymnia magnifica (Webster, 1884)

Eupolymnia rullieri Londoño-Mesa, 2009

Lanicola carus (Young \& Kritzler, 1987)

Loimia minuta Treadwell, 1929

Pista palmata (Verrill, 1873)

Streblosoma hartmanae Kritzler, 1971

\section{Taxonomic Section}

Family Amphinomidae

Savigny in Lamarck, 1818

Eurythoe complanata

(Pallas, 1766)

Material examined: Puerto Vargas, rock wash, $1 \mathrm{~m}$, col. R. Heard, May 9, 2001 (14 specimens).

Diagnosis: The body is elongate and the caruncle is much longer than wide with a smooth dorsum which overlaps its crenulated lateral surface. Branchiae begin on setiger 1 .

Distribution: This species has long been considered cosmopolitan on tropical reefs but molecular analysis by Barroso, Klautau, SoléCava and Paiva (2010) has found that there are at least 3 cryptic species. There is a Pacific species, an Atlantic/Caribbean coastal species extending from the Caribbean to Brazil, and an Atlantic islands species from Brazil and African islands.

\section{Hermodice carunculata}

(Pallas, 1766)

Material examined: Puerto Vargas, 959'39.01" N-8301'31.40” W, June 30 1994 (1).

Diagnosis: The body is elongate and the caruncle extends for about 4 segments. The caruncle is oval with deep transverse folds.

Distribution: This species is found on reefs throughout the Atlantic Ocean, including the Gulf of Mexico, the Caribbean Sea and the Mediterranean and Red Seas (Ahrens et al., 2013).

\section{Linopherus canariensis Langerhans, 1881}

Material examined: Puerto Vargas, rock wash, 1m, col. R. Heard, May 9, 2001 (1 MZUCR-373-11).

Diagnosis: The caruncle is small and hidden by the overlying peristomium and 7 pairs of branchiae are present first occurring on the second setiger. The short antennae and cirri are articulated and there are 2 pairs of eyespots with the second pair hidden under the overhanging peristomium.

Distribution: Linopherus canariensis has been reported from both sides of the Atlantic Ocean from the Canary Islands, Mexico, Cuba and perhaps Northeastern Brazil (Barroso \& Paiva, 2007). This species has more recently been reported as an invasive species in the Levantine and Aegean basins (Çinar, 2009) and from Sicily in the Mediterranean (Cosentino $\&$ Giacobbe, 2011). It is believed this species may be invasive due to its ability to reproduce rapidly by asexual fission.

\section{Family Capitellidae Grube, 1862 Dasybranchus lumbricoides} (Grube, 1878)

Material examined: Limón, rocky intertidal, 959'39.01" N-8301'31.40" W, June 30, 1994 (1).

Diagnosis: This specimen has 13 thoracic segments and the first setiger is complete with both notopodial and neuropodial capillaries. Dendritically branched branchiae occur in the posterior setigers. Neuropodial hooks with a large rounded hood, a main fang, and 3 small 
teeth above the main fang. Abdominal notopodia meet at the dorsum forming an essentially continuous line of hooks. Dean (2012) reports 3 species known from the Caribbean, D. caducas (Grube, 1846), D. lumbricoides, and D. lunulatus Ehlers, 1887. D. caducas lacks the almost continuous dorsal line of notopodial hooks seen here. D. lunulatus differs from this specimen in that it has fewer branchial lobes and a pair of pigmented eyespots which are lacking here.

Distribution: Dasybranchus lumbricoides has been recorded from Venezuela to Cuba in the Caribbean (Dean, 2012). This species is reported to occur in both the Atlantic and Pacific Oceans by López, Capa, Aguado and Cladera (2005).

Family Chaetopteridae

Audouin and Milne Edwards, 1833

Mesochaetopterus capensis

(McIntosh, 1885)

Material examined: Manzanillo, coral reef (taken while snorkeling), 9'38'12.86" N-82³9'15.90” W, Aug. 21, 2006 (numerous tubes, MZUCR-382-01).

Diagnosis: There are only 2 segments in the median region, the anterior region has 9 segments, and the palps extend past the median region. There are several setae in the $4^{\text {th }}$ setiger. The tubes are opaque and covered by sand grains.

Distribution: Mesochaetopterus capensis was described from South Africa and has been reported from the Caribbean and Gulf of Mexico (Glockner-Fagetti, 2009; Miloslavich et al., 2010; Dean, 2012). Habib and Mustaquim (1988) have also reported this species from the Indian Ocean off Pakistan.

\section{Family Chrysopetalidae Ehlers, 1864 Bhawania cf. goodei Webster, 1884}

Material examined: Cahuita Point, broken rock, 944'24.89' N-8250'35.93' W, May 14, 2011 (1).
Diagnosis: The caruncle is not folded and is hidden by the anterior paleae which have rounded tips, all of which are characteristic of the genus Bhawania. B. goodei Webster, 1884, B. heteroseta Perkins, 1985 and B. riveti (Gravier, 1908) have all been previously reported from the Caribbean (Dean, 2012). The neurosetae consist of an upper group of spinigers, a middle group of thin falcigers, and a lower group of short, stout falcigers, which is unlike the neurosetae described for $B$. riveti by Perkins (1985). Both $B$. riveti and $B$. heteroseta have a reduced number of paleae in the middle group (12 and 15 respectively) while this specimen has 26 middle group paleae which is agreement with the description of $B$. goodei by Perkins (1985). Mora-Vallín (2009), however, reports that she cannot find sufficient characters to differentiate $B$. goodei, $B$. riveti and B. brunnea Morgado and Amaral, 1981 and refers to specimens found in Caribbean Mexico as $B$. spp.

Distribution: This species was described from Bermuda by Webster (1884) and has been reported from many sites in the Caribbean (Dean, 2012).

\section{Family Cirratulidae Carus, 1863 Timarete punctata \\ (Grube, 1859) species complex}

Material examined: Cahuita, sea grass beds and coral rock, beach of seaweed bases, some rock, 9044'47.22" N, 8248'37.49" W, Aug. 22, 2006, col. H. Dean \& J. Cortes (2 MZUCR-378-01). Manzanillo, intertidal beach rock off reef, broken rock, $9^{\circ} 38^{\prime} 16.33^{\prime \prime}$ N-82³9'14.37' W, Aug. 28, 2009 (1). Manzanillo, coral reef, taken while snorkeling, 9038'12.86" N-82³9'15.90" W, Aug. 21, 2006 (1).

Diagnosis: Branchiae begin on setiger 1 and there are 5 pairs of tentacular cirri on setiger 3. Neuropodial spines begin at setiger 5 and notopodial spines at setiger 10. Branchiae are adjacent to the notopodial setal bundles anteriorly and posteriorly but in the midbody they are found more medial to the setal 
bundles. In life the body is mottled with bright green pigment spots and with similarly colored rings on the tentacular cirri but these become grey following fixation.

Distribution: This species was described from St. Croix in the Bahamas and has since been reported from many sites throughout the Caribbean (Dean, 2012) and as far South as the coast of Paraíba in Brazil. Magalhães, Seixas, Paiva and Elias (2014) has examined specimens from the Brazilian coast and found that $T$. punctata is most probably a complex of species. Cinar (2007) has examined the type specimens of this species and compared them to other material from the Indian Ocean, Western Atlantic and the Mediterranean Sea and found any morphological differences to be size dependent and, given its apparent absence in the Aegean Sea, indicated that members of this species complex may have migrated from the Red Sea to the Mediterranean through the Suez Canal.

\section{Family Eunicidae Berthold, 1827}

Eunice bucciensis

(Treadwell, 1921)

Material examined: Puerto Vargas, rock wash, $1 \mathrm{~m}$, col. R. Heard, May 9, 2001 (5, 7 MZUCR-373-15).

Diagnosis: The antennae and peristomial cirri are short and the aciculae are black, as are the bidentate subacicular hooks. Branchiae begin from setigers 12 to 15 and there is only a single filament. The mandibles are distally parallel. The aciculae are pointed, not expanded and the proximal tooth of the subacicular hooks is small and distally pointed.

Distribution: This species was described from Tobago by Treadwell (1921) and has also been reported from Caribbean Mexico (Salazar-Vallejo \& Carrera-Parra, 1997).

Eunice elegans

(Verrill, 1900)

Material examined: Puerto Vargas, rock wash, 1 m, col. R. Heard, May 9, 2001 (3).
Manzanillo Point, coralline rock, 9038'17.43"

N-82'38'58.21" W, Aug. 28, 2009 (1 MZUCR-376-01).

Diagnosis: The subacicular hooks are dark, honey-colored. Antennae and peristomial cirri are articulated; the antennae have teardrop shaped distal segments and the 3 to 4-segmented peristomial cirri reach to the middle of the prostomium. Branchiae are pectinate and begin at setiger 3, they are longer than the articulated dorsal cirri. Eyespots are posterior to antenna I and lateral to antenna II. Blades of the compound falcigers lack a mucron and the pectinate setae are heterodentate. Subacicular hooks are bidentate and there were up to 3 per parapodia. Aciculae in anterior parapodia are widened distally, some with a tiny hair-like extension.

Distribution: Verrill (1900) described this species from shallow water in Bermuda and this is the first record of this species in the Caribbean.

\section{Eunice fucata \\ Ehlers, 1887}

Material examined: South-east side of Cahuita Point, broken rock, 9044'20.14" N-8250’21.48”'W, May 14, 2012 (1).

Diagnosis: Unidentate, dark subacicular hooks began on setiger 39. Branchiae begin on setiger 5 and extend to the posterior of the incomplete specimen but are reported to be absent in posterior setigers in this species. Prostomial, peristomial appendages and dorsal cirri are all non-articulated; peristomial cirri reach to the mid prostomium.

Distribution: Eunice fucata was described from the Western side of Southern Florida in the Gulf of Mexico and has been reported from Cuba to the Barbados in the Caribbean (Dean, 2012).

Eunice goodei

Fauchald, 1992

Material examined: Cahuita, seagrass and brokenrock,Aug.22,2006(2,3 MZUCR-378-02). 
Manzanillo, intertidal beach rock, off reef, 9038'16.33" N-82'39'14.37' W, Aug. 28, 2009 (6). Manzanillo, coral reef (taken while snorkeling), 9038'12.86" N-82³9'15.90" W, Aug. 21, 2006 (2 MZUCR-382-02).

Diagnosis: Prostomial appendages, peristomial appendages, and dorsal cirri are all unarticulated. The bidentate subacicular hooks are dark with a smaller distal tooth facing upward; the acicula lack a mucron. Branchiae are lacking and subacicular hooks start at setiger 28. Maxilla III is short and curved forming a distal arc with maxilla IV.

Distribution: This species was redescribed and renamed by Fauchald (1992) from material originally named Nicidon kinbergi Webster, 1884 collected in Bermuda. It has been reported from Trinidad to Jamaica in the Caribbean (Dean, 2012).

\section{Eunice guanica}

(Treadwell, 1921)

Material examined: Manzanillo, intertidal beach rock, off reef, $9^{\circ} 38^{\prime} 16.33^{\prime \prime}$ N-82³9’14.37”' W, Aug. 28, 2009 (1).

Diagnosis: There are dark weakly bidentate subacicular hooks starting at setiger 17 . The antennae are articulated while the prostomial and dorsal cirri are not. The antennae are all similar in length and in a semicircle. Branchiae start at setiger 15, are longer than the dorsal cirri, and are considered to be palmate. The pectinate setae are isodont. Ventral cirri are spherical inflated posterior to setiger 5 .

Distribution: This species has been reported numerous times from the Caribbean from Colombia to Cuba (Dean, 2012).

\section{Eunice longisetis}

Webster, 1884

Material examined: Manzanillo intertidal beach rock, off reef, $9^{\circ} 38^{\prime} 16.33^{\prime \prime}$ N-82³9'14.37" W, Aug. 28, 2009 (1).

Diagnosis: The antennae, peristomial cirri and dorsal cirri are all annulated. The peristomial cirri are short and are approximately $2 / 3$ the length of the peristomium. Subacicular hooks are bidentate and honey colored. Dorsal and ventral cirri are digitate throughout the body. The acicula are pointed and the compound falcigers lack mucrons. Pectinate branchiae extend the length of the body. This species is somewhat similar to E. aphroditois but the palps are not subdivided as in that species and the branchiae are much more developed in E. longisetis.

Distribution: Eunice longisetis was described by Webster from material collected in Bermuda. Augener (1927) placed this species in synonymy with E. macrobranchia (Schmarda, 1861) described from the Cape of Good Hope, South Africa, however, in his review of the genus Eunice, Fauchald (1992) could not recognize the latter species as valid as it was so poorly described. Dean (2012) reported $E$. macrobranchia from Curaçao, Puerto Rico, and Venezuela, however, it is likely this was actually E. longisetis.

\section{Leodice rubra \\ (Grube, 1856)}

Material examined: Puerto Vargas, rock wash, 1m, col. R. Heard, May 9, 2001 (3, 1 MZUCR-373-02).

Diagnosis: The prostomial appendages are articulated with subspherical articles and the peristomial and dorsal cirri are also articulated. The yellow subacicular hooks are tridentate and the acicula of posterior segments are weakly bidentate. Two specimens were very small and were probably juveniles.

Zanol, Halanych and Fauchald (2014) used molecular and morphological techniques in the study of the phylogeny of the genus Eunice and found that Eunice rubra belonged to a distinct clade which they designated as Leodice. Leodice is characterized as having several, if not all, of the following characters. Articulated prostomial appendages, lateral dark spots between posterior parapodia (which occur in the present material), light, tridentate subacicular hooks, and tridentate compound falcigers. Of these characters, Leodice rubra only 
lacks the tridentate compound falcigers, having bidentate falcigers instead.

Distribution: This species was described from St. Thomas in the Caribbean and has been reported from many other Caribbean sites as well (Dean, 2012). Fauchald, Granados Barba and Solís-Weiss (2009) have also reported this species from the Gulf of Mexico.

\section{Lysidice caribensis}

Carrera-Parra, Fauchald \& Gambi, 2011

Material examined: Manzanillo, coral reef (taken while snorkeling), 9'38'12.86" N-82³9'15.90" W, Aug. 21, 2006 (1). Manzanillo point, coralline rock, 9०44'24.89" N-8250'35.93”' W, Aug. 28, 2009 (3 MZUCR381-01). Puerto Vargas, rock wash, $1 \mathrm{~m}$, col. R. Heard, May 9, 2001 (1).

Diagnosis: Both the subacicular hooks and aciculae are yellow throughout although in some specimens the aciculae have darkened tips. The pectinate setae are anodont throughout and are much wider posteriorly. The head is bilobed with a weak indentation.

Distribution: This species was described from Quintana Roo on the Caribbean coast of Mexico (Carrera-Parra et al., 2011) which was the first record from the Caribbean although many records of L. ninetta Audoin \& MilneEdwards, 1833 from this region could actually be $L$. caribensis.

\section{Marphysa longula (Ehlers, 1887)}

Material examined: Manzanillo, coral reef (taken while snorkeling), 9'38'12.86" N-82³9'15.90" W, Aug. 21, 2006 (1).

Diagnosis: The dark subacicular hooks are bidentate and branchiae are absent, characters which quickly identify this species.

Distribution: Dean (2012) reported records of this species from Venezuela, Colombia, Mexico and Cuba and de Assis et al. (2012) later also reported it from Brazil. De LeónGonzález and Díaz-Castañeda (2006) regard this species to be amphi-Atlantic as it has also been reported from the Canary Islands, Cape Verde Islands, and Senegal, as well as the Gulf of Guinea on the Western African coast.

\section{Marphysa veracruzensis}

de León-González and Díaz-Castañeda, 2006

Material examined: South side of Cahuita Point, broken rock, 9044'20.14" N-8250'21.48” W, June 14, 2011 (1).

Diagnosis: The bidentate subacicular hooks are yellow with 2 prominent teeth and the branchiae are pectinate which differentiates this species from $M$. orenzansi Salazar-Vallejo and Carrera-Parra (1997), described from Quintana Roo, Mexico. Pectinate branchiae begin at setiger thirty three and are single in the mid body, with 2 filaments posteriorly.

Distribution: Known from the Caribbean Sea from Mexico to Costa Rica.

\section{Palola siciliensis \\ (Moore, 1904)}

Material examined: South side of Cahuita Point, broken rock, 9'44'20.14”'N-82'50'21.48” W, May 14, 2011 (1 MZUCR-377-01).

Diagnosis: This species has been considered cosmopolitan and according to Salazar-Vallejo and Carrerra-Parra (1998) Palola siciliensis is the only species in the genus known from the Caribbean. Pepe (1985) reported it from Caribbean Costa Rica from intertidal rocks at Cahuita. Schulze (2006) and Schulze and Timm (2012) have found high haploid and nucleotide diversity in Caribbean samples from different islands but morphological variations were not apparent (even when compared to specimens from the Pacific Ocean).

Family Flabelligeridae de Saint-Joseph, 1894 Semiodera dubia (Treadwell, 1929)

Material examined: Manzanillo, intertidal beach rock, off reef, 9038'16.33" N-82'39'14.37" W, Aug. 28, 2009 (1). South side of Cahuita Point, broken rock, 
9044'20.14” N-82 50’21.48” W, May 14, 2011

(1 MZUCR-377-02).

Diagnosis: The smooth cylindrical body has small papillae lacking adherent sand grains with an anterior cephalic cage and a welldeveloped, sand encrusted dorsal shield. With double rows of large, closely spaced dorsal papillae anteriorly. Unidentate neurohooks begin at setiger 7 with median setigers possessing 4 subdistally swollen neurohooks.

Distribution: This species is reported to range from Florida in the Gulf of Mexico to Caribbean Panama (Salazar-Vallejo, 2012).

Semiodera treadwelli

Salazar-Vallejo, 2012

Material examined: Puerto Vargas, Limón, rock wash, $1 \mathrm{~m}$, May 9, $2001 \mathrm{col}$. R. Heard (1).

Diagnosis: Salazar-Vallejo (2012) reviewed species previously considered subgenera of either Piromis Kinberg, 1867or Pherusa Oken 1807 and defined the genus Semiodera Chamberlin, 1919 as having a defined dorsal shield, sessile branchiae on a branchial plate, and anchylosed neurosetae. The present specimen has a well-developed cephalic cage formed of long multiarticulated dorsal and ventral capillary setae in the first 4 segments. The number of branchiae could not be seen as most had broken off. In midbody and posterior segments the papillae lack adhering sand grains. Median setigers had 2 neurohooks per bundle and the dorsal shield is weakly developed with scattered sand particles which do not extend to the ventral surface.

Distribution: Salazar-Vallejo (2012) described this species from material collected by Treadwell from Puerto Rico but also included additional material from Quintana Roo, Caribbean Mexico, Grenada, and Southestern Brazil.
Family Glyceridae Grube, 1850

Hemipodia pustatula

(Friedrich, 1956)

Material examined: Mondonguillo. Pacuare, Limón, Subtidal 1 m, Sep. 15, 2006, col. Jeffrey Sibaja-Cordero (1 MZUCR-374-01).

Diagnosis: The ailerons are rod-like and uniramous parapodia occur throughout identifying this specimen as belonging to the genus Hemipodia. The proboscidial papillae have numerous U-shaped ridges and the presetal lobes are triangular with those in the posterior of the body with a small digitate tip.

Böggemann (2002) reports that Hemipodia armata (Hartman, 1950) (reported from Caribbean Costa Rica by Fauchald (1973) was described from a single poorly preserved specimen from Western Mexico. He suspects that $H$. armata should be synonymized with $H$. pustatula due to its slight morphological differences and the possibility that any differences may be products of sexual dimorphism.

Distribution: Böggemann (2002) describes the distribution of this species as from Mexico to Chile in the Eastern tropical Pacific and from Costa Rica to Brazil in the Atlantic and Caribbean. Böggemann (2002) has previously identified many specimens of this species from the Costa Rican Caribbean coast.

Family Lumbrineridae Schmarda, 1861

Scoletoma ernsti

(Perkins, 1979)

Material examined: Manzanillo, coral reef (taken while snorkeling), 9'38'12.86" N-82³9’15.90” W, Aug. 21, 2006 (1).

Diagnosis: With simple multidentate hooked hooks and capillaries and yellow aciculae. Maxilla I is subequal to maxilla II, maxilla 
III is bidentate, maxilla IV is unattached, and there was a ligament connecting maxilla I and II. The multidentate hooded hooks are present from setiger eighteen. The rounded parapodial lobes are enlarged in the posterior and the postsetal lobe extend laterally, not in a dorsal direction.

Distribution: Perkins (1979) described this species from Mississippi, Florida and the coast of North Carolina and it has been reported from Trinidad and Venezuela in the Caribbean (Dean, 2012).

\section{Family Maldanidae Malmgren, 1867 Axiothella sp.}

Material examined: Puerto Vargas, rock wash, 1 m, col. R. Heard, May 9, 2001 (1).

Diagnosis: The presence of an anal and cephalic plaque along with a terminal anus includes this species in the subfamily Euclymeninae. A single long medio-ventral cirrus with approximately thirty small, weakly developed radial cirri occur on the anal plaque. There are uncini, rather than acicular spines, in anterior segments and there is a single asetigerous preanal segment, all characteristic of the genus Axiothella.

Dean (2012) reported 2 species of Axiothella from the Caribbean Sea, A. isocirra Bleidorn and Hausen, 2007 and A. somersi (Verrill, 1900). Bleidorn and Hausen (2007) described $A$. isocirra as having 6 to 11 neuropodial uncini in setigers 4 through 16 and 15 equally long, radial anal cirri. According to Gillet (1989) A. somesi has 24 anal cirri which are alternately long and short and 2 asetigerous preanal segments. The specimen from Costa Rica has only 2 or 3 uncini per neuropodia in anterior segments and lacks neuropodial uncini posteriorly. Jiménez-Cueto and Salazar-Vallejo (1997) point out that the number of neuropodial uncini is highly size dependent in $A$. mucosa (Andrews, 1891) and Bleidorn and Hausen (2007) later found the same to be true for $A$. isocirra. The low number of uncini in anterior setigers of Axiothella sp. may be an indication that this is a juvenile specimen making further identification impossible.

\section{Family Nereididae Blainville, 1818 Ceratonereis excisa \\ (Grube, 1874)}

Material examined: Cahuita, seagrass and broken rock, 9०44'47.22" N-82'48'37.49" W Aug. 22, 2006 (1). Puerto Vargas, rock wash, $1 \mathrm{~m}$, col. R. Heard, May 9, 2001 (2 MZUCR-373-10).

Diagnosis: The prostomium is split anteriorly and the notopodial ligules are well developed anteriorly but reduced in posterior segments. The homogomph neuropodial falcigers are unidentate with a sharply bent apex and fine hairs increasing in length distally. There is a small oval of sixteen pectinate paragnaths in area II while in area III there are 4 pectinate paragnaths. In region IV there are 6 conical paragnaths in a small circular patch.

Distribution: Ceratonereis excisa was described from Brazil but was suggested to be put into synonymy with $C$. miribilis by Ehlers (1887). Dean (2012) erroneously followed this synonymy but Perkins (1980) retained C. exci$s a$ as a valid species as did Ibarzábal (1986), Salazar-Vallejo and Jiménez-Cueto (1997), de León-González, Solís-Weiss and Ochoa-Rivera (1999), and de León-González (2009). This species has also been reported from many sites in the Caribbean (Dean, 2012).

\section{Ceratoneris irritabilis}

(Webster, 1879)

Material examined: South side of Cahuita Point, broken rock, 9044'20.14" N-8250'21.48” W, May 14, 2011 (1).

Diagnosis: The prostomium is not split and the dorsal and medial ligules are well developed in anterior setigers. Notopodial falcigers are lacking and neuropodial falcigers are unidentate with a rounded apical tip. Proboscis area I lacks paragnaths, area II with $8-10$, area III with 1 large and 2 small paragnaths, area IV with 8-9. Webster (1879) and Taylor (1984) 
reported 2 rows of numerous small paragnaths in area III for this species but variability in paragnath number has been shown to exhibit great inter-population variability and the use of paragnath number as a determinate of species in the Nereididae has been questioned (Maltagliati, Massaro, Cossu, \& Castelli, 2006).

Distribution: Ceratoneris irritabilis has been reported from Virginia (USA), the Gulf of Mexico (Taylor, 1984) and many sites in the Caribbean (Dean, 2012).

Nereis cf grayi

Pettibone, 1956

Material examined: Puerto Vargas, rock wash, $1 \mathrm{~m}$, col. R. Heard, May 9, 2001 (1 MZUCR-373-06).

Diagnosis: This is a small specimen $(6 \mathrm{~mm}$ in length). There are 2 or 3 paragnaths in area VI and none in areas VII-VIII. On the maxillary ring are 7 paragnaths in area II and 4-5 in area IV. Notopodial falcigers are homogomph with a short unidentate falciger with 2 or 3 inconspicuous fine teeth. Notopodia are present but not enlarged posteriorly. The second setiger has a brown transverse pigment band and the tentacular cirri are segmented. Both Pettibone (1956) and Taylor (1984) described the homogomph falcigers as short and smooth but de León-González (2009) noted the presence of 2 inconspicuous fine teeth on the notopodial falcigers.

Distribution: Pettibone (1956) described this species from Massachusetts in the Western North Atlantic and Taylor (1984) reported this species throughout the Gulf of Mexico. This is the first report of this species from the Caribbean.

Nereis riisei

Grube, 1857

Material examined: Manzanillo Point, coralline rock, 9038'23.38" N-82³8'58.21" W, Aug. 28, 2009 (1 MZUCR-383-01). South side of Cahuita Point, broken rock, 9044'20.14" N-82'50'21.48” W, May14, 2011 (1).
Cahuita, seagrass and broken rock, $9^{\circ} 44^{\prime} 47.22^{\prime \prime}$ N-8248'37.49”'W, Aug. 22, 2006 (2). Limón, beach wall, rocky intertidal, 9'59'39.01" N-8301'31.40" W, June 30, 1994 (1). Puerto Vargas, rock wash, col. R. Heard, May 9, 2001 (3 MZUCR-373-17).

Diagnosis: Homogomph notopodial falcigers are present in middle and posterior setigers and they are similar to those shown in de LeónGonzález (2009, Fig. 9A) with a folded apex and fine proximal hairs. Paragnaths $\mathrm{I}=2-4$ in a line, II = 23-29, III = 21-41, IV $=34-38, \mathrm{~V}=0$, $\mathrm{VI}=7-13$, VII \& VIII $=7$ in a single line. One specimen from the rocky intertidal of Limón was a female epitoke. Notopodial falcigers are absent and paragnaths are fewer than in nonepitokous specimens, I $=1$, II $=21-22$, III = $21, \mathrm{IV}=28, \mathrm{~V}=0, \mathrm{VI}=5-6, \mathrm{VII} \& \mathrm{VII}=5$. The epitokeous region begins at setiger 25 with the appearance of a flat, ovoid flange proximal to the base of the dorsal and ventral cirri and a flattening of all parapodial lobes. Notosetae are reduced in number and size with notopodial falcigers absent. Long natatory setae emerge from the proximal region of the upper notopodial and lower neuropodial lobes beginning on setiger twenty seven.

Distribution: De León-González et al. (1999) report this species as occurring on both sides of the Americas. In the Western Atlantic it has been reported from North Carolina (Gardiner, 1976) to the Gulf of Mexico (de León-González et al., 1999). It has also been reported from many sites throughout the Caribbean (Dean, 2012).

\section{Perinereis sp.}

Material examined: Manzanillo, intertidal coralline rocks, next to reef, $9^{\circ} 38^{\prime} 16.33^{\prime \prime}$ N-82'39'14.37" W, Aug. 28, 2009 (24). Cahuita Point, broken rock, 9'44'24.89" N-82 ${ }^{\circ} 50$ '35.93” W, May 14, 2011 (4). South side of Cahuita Point, broken rock, 9044'20.14" N-8250’21.48”'W, May 14, 2011 (1).

Diagnosis: The presence of paragnaths on all areas of the pharynx and transverse bars on area VI place this in the genus Perinereis. 
Paragnath distributions; $\mathrm{I}=9-16, \mathrm{II}=15-24$, III $=18-25, \mathrm{IV}=23-30, \mathrm{~V}=1, \mathrm{VI}=1$ transverse bar, VII \& VIII $=2$ rows of paragnaths, eighteen to twenty two in the proximal row and 12 to 17 in the distal row. The dorsal ligules are elongate in the posterior with the dorsal cirri emerging sub-distally. The anterior dorsum is dark purple in fixed material and there are middorsal pigment spots posteriorly.

Distribution: This species is very similar to P. elenecasoae Rioja, 1947 and de LeónGonzález \& Solís-Weiss (1998) reported it as such from Quintana Roo, Mexico. That species is now known to only occur in the East Pacific (de León-González, 2009). Upon examination of specimens of Perinereis sp. from Caribbean Mexico and Costa Rica, De León-González (pers. comm.) believes that they are specimens of $P$. ponteni Kinberg, 1866 which had previously been synonymized with $P$. anderssoni Kinberg, 1866. In her doctoral dissertation, Lana (1984) illustrated these 2 species and indicated their synonymy was incorrect.

\section{Platynereis dumerilii \\ (Audouin \& Milne-Edwards, 1933)}

Material examined: Puerto Vargas, rock wash, 1 m, col. R. Heard, May 9, 2001 (11, 6 MZUCR-373-04).

Diagnosis: The presence of pectinate paragnaths in a triangular patch in area IV identifies this species as belonging in the genus Platynereis. Composite notopodial, unidentate falcigers as well as the 5 groups of pectinate paragnaths in areas VII and VIII identify this as $P$. dumerilii. There is a line of about 9 paragnaths in area VI and in area III there were 6-8 paragnaths. The 6 paragnaths on area III as opposed to only 3 reported for the similar $P$. mucronata de León-González, Solís-Weiss and Valadez-Rocha (2001) and the 9 paragnaths in area IV as opposed to only 4 in P. mucronata help separate these 2 species.

Distribution: Perinereis dumerilii has been reported to be cosmopolitan in tropical and subtropical waters and has been reported from many sites throughout the Caribbean Sea (Dean, 2012).

Family Oenonidae Kinberg, 1865

Arabella multidentata (Ehlers, 1887)

Material examined: Puerto Vargas, rock wash, $1 \mathrm{~m}$, col. R. Heard, May 9, 2001 (1 MZUCR-373-07). Portete, from coralline rock, $10^{\circ} 00$ '35.91" N-8303'17.43" W June 30, 1994 (1). Manzanillo, coral reef (taken while snorkeling), 9'38'12.86" N-82 $39^{\circ}$ '15.90" W, Aug. 21, 2006 (2).

Diagnosis: There are five pairs of maxillae and both occipital antennae and acicular spines are absent thus identifying this as in the genus Arabella Grube, 1850. Maxillae II are symmetrical and posterior notopodial lobes are present but not erect as in A. panamensis Colbath (1989). There are 4 eyespots at the posterior prostomium as well as an additional small spot slightly anterio-lateral to the mid-line.

Distribution: Colbath (1989) reported Arabella multidentata to range from Virginia (USA) to Caribbean Panama in the Western Atlantic Ocean. This species has been reported from Colombia, Panama and Puerto Rico in the Caribbean (Dean, 2012) although many other reports of A. iricolor (Montagu, 1804) from the Caribbean may actually be $A$. multidentata . As pointed out by Perkins (1979) and Colbath (1989), attempts to synonymize $A$. multidentata with are $A$. iricolor are incorrect as $A$. iricolor lacks the abruptly tapering ventral setae of $A$. multidentata. In the review of Oenonidae of Mexico by Carrera-Parra (2009) A. multidentata is recognized as separate from $A$. iricolor and is also reported from Caribbean Mexico.

$$
\begin{gathered}
\text { Family Onuphidae Kinberg, } 1865 \\
\text { Diopatra cuprea } \\
\text { (Bosc, 1802) }
\end{gathered}
$$

Material examined: Limón, Moín, Isla Pájaros, bottom trawl net col. Karina Rodriguez, July 25, 2006 (5 MZUCR-372-01).

Diagnosis: Peristomial cirri are present and the branchiae are spiralled, identifying 
this as a member of the genus Diopatra. The ceratophores and palpophores lack papillae, the pseudocompound setae are bidentate, and the pectinate setae are straight-edged with small numerous fine teeth. Numerous rows of fine sensory papillae were present on the ceratophores similar to those indicated for this species by Budaeva and Fauchald (2008). One smaller individual had scattered brown spots on the dorsal surface and light brown bands around the antennae but other specimens were colorless in alcohol.

Distribution: Diopatra cuprea is reported in the Western Atlantic Ocean from New England to Brazil, including the Gulf of Mexico and the Caribbean, as well as East and South Africa in the Eastern Atlantic and the Indian Ocean (Budaeva \& Fauchald, 2008). It has been reported from Colombia, Cuba, Panama, Trinidad, and Venezuela in the Caribbean (Dean, 2012).

\section{Family Opheliidae Malmgren, 1867 Polyophthalmus pictus}

(Dujardin, 1839)

Material examined: Manzanillo Point, coralline rock, 9³8'23.38" N-82³8'58.21" W, Aug. 28, 2009 (1).

Diagnosis: The body is elongate with a ventral groove extending the entire length of the body. Lateral eyespots are present while branchiae are absent. The head is rounded with a pair of small embedded eyespots. An irregular transverse line of brown pigment spots extends across the dorsum of each segment with a much denser region of pigment spots in the most anterior segments. The anal funnel is small with several small anal papillae.

Distribution: Hartman (1965) considered there to be only 3 valid species in the genus Polyophthalmus; P. pictus (Dujardin, 1839), P. striatus Kükenthal, 1887 described from Hong Kong, and P. translucens (Hartman, 1960) from the deep Pacific Ocean. P. pictus is considered a cosmopolitan species and has been collected from many locations throughout the Caribbean Sea (Dean, 2012). Purschke, Ding and Müller
(1995) have found ultrastructural differences between the eyespots of specimens from China and Italy and have therefore established a new species, P. quingdaoensis Purschke, Ding and Müller (1995), for the Chinese specimens. Perhaps further analyses will reveal $P$. pictus to be a complex of crypto-species.

\section{Family Pilargidae de Saint-Joseph, 1899 Synelmis sotoi Salazar-Vallejo, 2003}

Material examined: South side of Cahuita Point, broken rock, 9044'20.14" N-8250’21.48” W, May 14, 2011 (1).

Diagnosis: Lateral antennae occur on the middle of the prostomium and there are 3 pairs of irregularly spaced eyespots. Submedial pigmented glands occur in the parapodial cirri which are larger than the parapodial lobes. The dorsal cirrus is smaller than the ventral cirrus in mid and posterior setigers. Notospines begin at setiger nineteen and the furcate setae are slightly asymmetrical.

Distribution: Salazar-Vallejo (2003) described this species from the Florida Keys, Caribbean Mexico, Puerto Rico, Antigua and the North coast of Brazil.

\section{Family Polynoidae Malmgren, 1867 Halosydna leukohyba Schmarda, 1861}

Material examined: South side of Cahuita Point, broken rock, 9०44'20.14" N-8250’21.48”' W, May 14, 2011 (1).

Diagnosis: Lateral antennae are terminal and the tentacular cirri are attached to the prostomium. The neurosetae are bidentate and the notosetae are short and blunt ending and longer and slender. There are thirty two body segments with 18 slate gray elytra with rounded macrotubercles on their posterior and white microtubercles. Sclerotized microtubules occur on the first elytra differentiating this species from H. silvamariae Salazar-Silva (2013) from Baja, California, Mexico in the Eastern Pacific. 
Distribution: Salazar-Silva (2013) reports the type locality as Jamaica and includes material from Bermuda, Florida, Mexico, Puerto Rico, Venezuela, and the Virgin Islands in her review of the genus Halosydna Kinberg, 1856. Dean (2012) cites numerous records in the Caribbean from Cuba to Barbados.

\section{Harmothoe muiri \\ Salazar-Silva, 2010}

Material examined: Puerto Vargas, rock wash, $1 \mathrm{~m}$, col. R. Heard, May 9, 2001 (2 MZUCR-373-16).

Diagnosis: There are 2 specimens, 1 with only a single elytron, the other being only an anterior fragment. The large macrotubules on the elytra are subterminal and separated from each other, somewhat swollen; in medial segments there are small distal tooth-like peaks and are more flattened. The neurosetae are spinous for more than $3 / 4$ of the upper region differentiating this species from the similar $H$. augeneri Salazar-Silva (2010) from Caribbean Panama which has spines only up to $3 / 4$ the upper region of the neurosetae.

Distribution: Harmothoe muiri had been known previously only from the type locality, Quintana Roo, Caribbean Mexico (SalazarSilva, 2010).

\section{Harmothoe polytrichoides Augener, 1922}

Material examined: Manzanillo intertidal beach rock, off reef, $9^{\circ} 38^{\prime} 16.33^{\prime \prime}$ N-82³9'14.37' W, Aug. 28, 2007 (1).

Diagnosis: The elytra have a fringe of long papillae and the scattered, cylindrical macrotubercles have 4 bifurcate arms characteristic of H. polytrichoides.

Distribution: Salazar-Silva (2010) reported this species from the Mexican Caribbean, Guana Island and St. Thomas, both in the Virgin Islands, and South to Brazil although specimens from Brazil were reported to have shorter dorsal cirri and shorter, more abundant, macrotubules than those of Caribbean specimens.

\section{Hermenia verruculosa}

Grube, 1857

Material examined: Portete, coralline rock, $10^{\circ} 00^{\prime} 35.91^{\prime \prime} \mathrm{N}-83^{\circ} 03^{\prime} 17.43^{\prime \prime} \mathrm{W}$ June 30, 1994 (1).

Diagnosis: There are thirteen elytra with the first pair largest and the remainder small button-like discs that are often mistaken as elytral scars. The dorsal surface of the body is covered with rounded tubercles and the ventral surface with fine papillae. Pettibone (1993) mentioned that the dorsal tubercles were quite similar to the ophiuroid upon which the specimens were found. Notosetae are short and serrate with only 1 or 2 per fascicle; the bidentate neurosetae are large with a smooth shaft.

Distribution: Known to occur at Belize, Cuba, Curaçao, Guadeloupe, and St. John in the Caribbean (Dean, 2012). Pettibone (1975) also reported specimens from off New Jersey, the Gulf of Mexico, and as far South as Colombia (South America) from the intertidal to 223 meters.

\section{Lepidonotus lacteus (Ehlers, 1887)}

Material examined: Cahuita Point, Coralline rock, 9०44'24.89' N-8250'35.93” W, May 14, 2011 (1).

Diagnosis: The conical microtubercles with a roughly pentagonal, unpigmented, basal region on the elytra, the smooth palps, and the finely serrated neurosetae agree with Ehler's (1887) original description.

Distribution: Ehlers (1887) described this species from Florida and it has more recently been reported from the Gulf of Mexico by Fauchald et al. (2009). Augener (1906) collected this species from Barbados, Guadeloupe, Montserrat, and St. Vincent in the Caribbean.

\section{Lepidonotus sublevis Verrill, 1873}

Material examined: Puerto Vargas, rock wash, $1 \mathrm{~m}$, col. R. Heard, May 9, 2001 (1 MZUCR-373-05). 
Diagnosis: This incomplete specimen has unidentate, coarsely serrated, neurosetae, the conical microtubercles of the elytra lacked an unpigmented areolar region, and the palps are papillated. Long papillae occur only on the external border of the elytra.

Distribution: This species was originally described from New England (USA) and Pettibone (1963) reported it to range Southward to the Gulf of Mexico. It has also been reported from Colombia, Cuba and Trinidad in the Caribbean (in Dean, 2012).

\section{Lepidonotus variabilis \\ Webster, 1879}

Material examined: Puerto Vargas, rock wash, $1 \mathrm{~m}$, col. R. Heard, May 9, 2001 (2 MZUCR-373-12).

Diagnosis: The neurosetae are bidentate with a smaller subdistal tooth and the palps are smooth. The elytra have long marginal papillae on the exterior and posterior border. The extra tuft of papillae on the posterior border of the elytra, mentioned by Gardiner (1976), was present on the median elytra.

Distribution: San Martín, Aguirre and Baratech (1986) cites the range of L. variabilis from Massachusetts (USA) to the Caribbean. Dean (2012) reports records from Colombia, Cuba, Panama, Puerto Rico and Trinidad in the Caribbean and Fauchald et al. (2009) also report it from the Gulf of Mexico.

\section{Family Sabellariidae Johnston, 1865 Sabellaria floridensis Hartman, 1944}

Material examined: Puerto Vargas, seagrass and broken rock, 9044'47.22" N-8248'37.49”' W, Aug. 22, 2006 (1).

Diagnosis: There are 3 segments in the parathorax and the corona and operculum are partially split. There are 3 rows of paleae with the second row being long and spine-like and the outer row denticulate. Dos Santos, Riul, Santos, Brasil and Christoffersen (2011) reports that $S$. floridensis differs from the similar species S. bella Grube, 1870, which they reported from Brazil, in that its outer paleae have a longer middle plume which bends towards the inner rows of paleae while those of $S$. bella are shorter and more erect. Liñero Arana (2013), however, feels these 2 species may need to be synonymized.

Distribution: Sabellaria floridensis was described from the Gulf of Mexico coast of Florida (USA) and has been reported from the coasts of North Carolina and Georgia as well as from Cuba to Venezuela in the Caribbean (Liñero-Arana, 2013).

\section{Family Sabellidae Latreille, 1825} Bispira melanostigma

(Schmarda, 1861)

Material examined: Puerto Vargas, seagrass beds and coralline rock, 9०44'47.22" N-8248'37.49”' W, Aug. 22, 2006 (1).

Diagnosis: The thorax is as wide as long and there are paired eyespots on the radioles. Uncini are avicular with a short manubrum and companion setae are somewhat scoop-shaped similar to those shown in Knight-Jones and Perkins (1998). Abdominal parapodia are conical lobes with neurosetae in a C-shaped arrangement.

Distribution: Bispira melanostigma was described from Jamaica and has been reported in many Caribbean sites (Dean, 2012). Giangrande, Licciano and Gambi (2007) reported it from Belize and noted that it is also found in the Gulf of Mexico, Bermuda, and the Southeastern United States on corals and other hard substrates from the lower intertidal to shallow subtidal depths.

\section{Megalomma perkinsi}

Tovar-Hernández and Salazar-Vallejo, 2006

Material examined: Manzanillo, coral reef (taken while snorkeling), 9'38'12.86" N-82³9'15.90” W, Aug. 21, 2006 (1).

Diagnosis: Eyespots were present on most of the radioles and the dorsal collar was joined to the fecal groove (although Perkins (1984) 
originally described them as unattached). Dorsal lappets are present and the inferior thoracic setae are elongate and pointed (the type A setae of Tovar-Hernández and Carrera-Parra (2011)).

Distribution: Tovar-Hernández and Carrera-Parra (2011) gave the range of this species as from North Carolina in the Eastern Atlantic, Western Florida in the Gulf of Mexico, and Caribbean Panama.

\section{Notaulax nudicollis \\ (Krøyer, 1856)}

Material examined: Manzanillo Point, broken rock, 9०44'24.89" N-82'50'35.93" W, Aug. 28, 2009 (1 MZUCR-384-01). Cahuita Point, coralline rock, 9०44'24.89" N-8250'35.93” W, May 14, 2011 (1).

Diagnosis: The presence of rounded palaea in the abdominal neuropodia and the transverse row of setae on the first setiger help identify this as belonging in the genus Notaulax. The non-incised ventral collar which is equal in length to the second setiger, and a group of numerous ocelli on each radiole identify this as $N$. nudicollis.

Distribution: This species was described from St. Thomas in the Virgin Islands and has been reported from numerous sites in the Caribbean (Dean, 2012). Tovar-Hernández and Salazar-Vallejo (2006) also reported it to occur in Florida and Mexico in the Gulf of Mexico and cast doubt on Perkin's (1984) report of this species from Pacific Mexico. De Assis, Alonso, de Brito, Dos Santos and Christoffersen (2012) has more recently reported this species from São Paulo, Brazil, in the Southwestern Atlantic.

\section{Notaulax occidentalis}

(Baird, 1865)

Material examined: South side of Cahuita Point, broken rock, 9०44'20.14" N-8250’21.48”' W, May 14, 2011 (1).

Diagnosis: The brachial region is short relative to the body. Abdominal palaeate neurosetae are rounded with a distal point similar to those figured by Tovar-Hernández and
Salazar-Vallejo (2006) for this species. The long, spinous setae on the first setiger are in a single row and are also similar to that shown in Tovar-Hernández and Salazar-Vallejo (2006). There are 8 thoracic segments and the ventral collar is incised while the dorsal collar is only weakly so. The "ocelli are numerous and irregularly arranged in long single rows" as stated in Perkins (1984). The companion setae have very long stalks.

Distribution: Notaulax occidentalis was described from St Vincent in the Virgin Islands and has been reported from many sites in the Caribbean (Dean, 2012). De Assis et al. (2012) have reported it to range from North Carolina to the Northern Brazilian coast.

\section{Parasabella jamaicensis}

(Augener, 1922)

Material examined: Cahuita, seagrass and broken rock, 9०44'47.22" N-82'48'37.49" W, Aug. 22, 2006 (3).

Diagnosis: The thoracic neurosetae are avicular and the thick companion setae have a long mucron. Abdominal neuropodia are capillaries accompanied by pointed, narrow-bladed neurosetae. The ventral lips are triangular and well developed and the neuropodial tori of the thorax extend to, and indent into, the ventral shields. Radioles lack ocelli and are colorless.

Distribution: This species was described by Augener (1922) from Kingston, Jamaica and has also been reported from Puerto Rico and Venezuela (Dean, 2012) as well as Saint Thomas in the Virgin Islands (Tovar-Hernández \& Salazar-Vallejo, 2006) and Belize (Giangrande et al., 2007).

\section{Pseudopotamilla fitzhughi}

Tovar-Hernández and Salazar-Vallejo, 2006

Material examined: South side of Cahuita Point, broken rock, 9044'20.14" N-8250’21.48”' W, May 14, 2011 (1).

Diagnosis: Thoracic uncini are avicular with a manubrial length twice the distance from the crest to the base of the uncinar breast. 
There are 8 thoracic segments and paleae are present in the inferior thoracic notopodium. Abdominal capillary neurosetae are in a line, paleae are absent, and the manubrum is short in notopodial tori. Compound eyes are present proximally on the radioles with the most distal being small and rounded and the remaining 2 to 3 eyes on the radioles densely packed ocelli.

Distribution: This species was described from the Mexican Caribbean and was also collected in the Gulf of Mexico and Curaçao (Tovar-Hernández \& Salazar-Vallejo, 2006).

\section{Family Sigalionidae Malmgren, 1867 Fimbriosthenelais hobbsi}

Pettibone, 1971

Material examined: Puerto Vargas, rock wash, 1m, col. R. Heard, May 9, 2001 (1).

Diagnosis: Lateral antennae are attached to the parapodial base and auricles are present. Papillated stylodes occur on the parapodia and there are compound falcigers in the neuropodia. The bidentate neurosetae have 4 rows of small spines on the manubrium. Elytra have dispersed microtubercles and long papillae on the lateral edge. The first several setigers have multiarticulated neurosetae, in addition to the bidentate falcigers. All neurosetae are bidentate falcigers in subsequent setigers. Branchiae begin on setiger 6 .

Distribution: Pettibone (1971) described this species from a specimen collected at Isla de la Juventud, Cuba and Sheridan (1997) later reported it from seagrass beds in Southwest Florida.

Family Spionidae Grube, 1850

Prionospio (Prionospio) cf. heterobranchia Moore, 1907

Material examined: Cahuita, seagrass and broken rock, 9०44'47.22" N-82 ${ }^{\circ} 48^{\prime} 37.49$ " W, Aug. 22, 2006 (1).

Diagnosis: There are five pairs of branchiae beginning on setiger 2 with the second and third branchiae apinnate and the remaining 3 pinnate. Maciolek (1985) found the first and fifth branchiae to be longest and of equal length in $P$. heterobranchia but in this specimen the fourth branchiae, although pinnate, are flattened similarly to branchiae 2 and 3 and are shorter. The fifth pair of branchiae is pinnate but narrow and only half the length of the first pair of branchiae. The ventral cirrus on setiger 2 is long and digitate. Sabre setae first occur on setiger twelve and the hooks on setiger fourteen.

Distribution: Prionospio heterobranchia has been reported from many sites in the Caribbean (Dean, 2012) and has also been reported from the Gulf of Mexico and California (USA) (Maciolek, 1985).

\section{Family Syllidae Grube, 1850 Branchiosyllis lorenae San Martín \& Bone, 1999}

Material examined: Puerto Vargas, rock wash, 1 m. col. R. Heard, Oct. 9, 2001 (7).

Diagnosis: This has the claw-like deflexed compound setae in posterior setigers, as well as an anterior dorsal tooth on the pharynx. There are no branchiae on the parapodial lobes and the anterior setae have long, curved bidentate blades. The dorsal cirri are long, about thirty segments, and of equal size.

Distribution: This species is known in the Caribbean from Cuba and Venezuela (Dean, 2012), having been described from Venezuela.

\section{Eusyllis lamelligera \\ Marin \& Bebretzky, 1875}

Material examined: Puerto Vargas, rock wash, 1 m, col. R. Heard, May 9, 2001 (4).

Diagnosis: The cirri are smooth and the palps partially fused at the base. There is a dorsal tooth near the pharynx opening plus a ridge of very small teeth along each side of the pharynx. Ventral cirri are attached at the base of the parapodial lobe and the ventral cirri at the base of setiger 1 are broad and laminar.

Distribution: Eusyllis lamelligera is a geographically widespread species. Aguado, Martín and Hove (2008) reported this species 
from the West Atlantic Ocean (North coast of the U.S.A. to Cuba), East Atlantic Ocean (from English Channel to Canary Islands), Mediterranean, Pacific Ocean (Australia), Indian Ocean (Australia), and Indonesia. Brusa, Aguado, San Martín and Rouse (2013) later reported its distribution as the North Eastern Atlantic (English Channel to Canary Islands), North Western Atlantic (U.S.A. to Cuba), Mediterranean Sea, and the Pacific Ocean (Australia and Japan).

\section{Exogone rolani}

San Martín, 1991

Material examined: Puerto Vargas, rock wash, 1 m, col. R. Heard, May 9, 2001 (1).

Diagnosis: The median antenna is longer than the papilliform laterals and a dorsal cirrus is present on the second setiger. The shafts of the compound spinigers of setiger 2 lack a subdistal triangular process and the bidentate falcigers of setigers 1 to 5 have a long subdistal tooth subequal to the blade. These long subdistal teeth in anterior setigers differentiate this species from the widespread Exogone dispar (Webster, 1879).

Distribution: San Martín (1991) described this species from Cuba and also collected it from the East coast of Southern Florida in the Atlantic. Paresque, Fukada and Nogueira (2014) also collected it from the intertidal to $52 \mathrm{~m}$ depth in Paraíba, Rio de Janeiro, Brazil.

\section{Haplosyllis niphatesicola Lattig \& Martin, 2011}

Material examined: Puerto Vargas, rock wash, 1 m, col. R. Heard, Oct. 9, 2001 (1).

Diagnosis: Ventral cirri are present and the palps are fused at the base. The antennae and cirri are clearly articulated and the simple setae have a large proximal tooth and 2 small distal teeth.

Lattig and Martin (2011) reviewed the genus Haplosyllis Langerhans, 1879 from the Caribbean and described four new species. Of the Caribbean species reviewed, $H$. niphatesicola is most similar to $H$. cephalata Verrill, 1910 but differs in the possession of alternating long (5-9) and short (1-4) dorsal cirri in mid body setigers. It also differs from $H$. chaetafusorata Lattig and Martin (2011) in having distally curved aciculae, and from $H$. aplysinicola Lattig \& Martin, 2011 in having a larger and sharper main fang on the thick simple setae and small dorsal granules throughout the body surface.

Distribution: Species of Haplosyllis are found in association with sponges and gorgonians, most likely in a commensal relationship (see diagnosis in Lattig \& Martin, 2011). Lattig and Martin (2011) described this species from sponges in Belize and Colombia and the single specimen collected from calcium carbonate rocks at Puerto Vargas was presumably living on, or in, a sponge on those rocks.

\section{Odontosyllis enopla Verrill, 1900}

Material examined: Puerto Vargas, rock wash, 1 m, col. R. Heard, May 9, 2001 (1). Puerto Vargas, rock wash, $1 \mathrm{~m}$, col. R. Heard, Oct. 9, 2001 (1 MZUCR-375-02).

Diagnosis: There is a subdistal row of small denticles on the aciculum and the pharynx has 6 teeth and 2 lateral plates. The pharynx is approximately 6 setigers in length and the proventriculus has 34 muscle bands. The dorsal cirri alternate in length, with the longer cirri subequal to the segment width. The short-bladed compound setae are bidentate with subequal teeth and differ from those of the similar species O. twincayensis Russell, 1989, described from Belize, which has longer blades. Odontosyllis enopla also differs from O. fulgurans (Audouin \& Milne Edwards, 1833), described from the Mediterranean Sea, in the length of its pharynx which is 6 to 7 segments as compared to 2 to 3 in O.fulgurans.

Distribution: This species has been reported from Barbados, Bermuda, Gulf of Mexico, and Venezuela (San Martín \& Bone, 2001; Liñero-Arana \& Díaz Díaz, 2011). 
Odontosyllis guillermoi

Fukuda \& Nogueira, 2006

Material examined: Puerto Vargas, rock wash, $1 \mathrm{~m}$, col. R. Heard, May 9, 2001 (2 MZUCR-373-01).

Diagnosis: The pharynx has 6 teeth with a lateral plate on each side and the proventriculus extends about fifteen segments with approximately sixty muscle bands. Compound setae are bidentate with the distal tooth larger than the proximal tooth which is situated some distance away. Anterior parapodia have 4 to 5 aciculae with a subdistal corona of denticles. A pair of transverse dark brown pigment stripes occur on each anterior segment and there is light pigment on the prostomium surrounding each eyespot region (referred to in this species by Fukuda and Nogueira (2006) as a "mask").

The elongate proventriculus and the longer, straighter blades of the compound setae distinguish this species from $O$. fulgerans Additionally, $O$. fulgerans has only 2 aciculae per parapodium and is not pigmented. The elongate proventriculus also distinguishes this species from $O$. twincayensis and the numerous aciculae distinguish it from $O$. longigulata Perkins, 1981, described from the East coast of Southern Florida, which also has an elongate proventriculus but only has a single acicula per parapodium.

Distribution: Odontosyllis guillermoi is previously known from the type locality region of the State of Sao Paulo, Brazil, and Margarita Island, Venezuela (Liñero Arana \& Díaz-Díaz, 2011).

\section{Syllis beneliahuae \\ (Campoy \& Alquezar, 1982)}

Material examined: Puerto Vargas, rock wash, 1m, col. R. Heard, May 9, 2001 (1). Manzanillo, coral reef (taken while snorkeling), 9038'12.86" N-82 $39^{\circ}$ '15.90" W, Aug. 21, 2006 (1).

Diagnosis: Dorsal cirri in the mid-body alternated with eight to fourteen and eighteen to twenty segments. Pseudospinigers are present and there are 8 to 9 setae in anterior parapodia. There were 3 aciculae in anterior parapodia and 2 in mid-body parapodia; a needle-like aciculum accompanied these thicker acicula in all setigers. This species differs from the similar S. garciai (Campoy, 1982) in its greater number of aciculae, while the latter species has only 2 aciculae per parapodium.

Distribution: Syllis beneliahuae was described from the Mediterranean, and has also been reported from the Eastern Atlantic (Licher, 1999), and Mexico and Venezuela in the Caribbean (Dean, 2012).

\section{Syllis broomensis}

(Hartmann-Schröder, 1979)

Material examined: Puerto Vargas, rock wash, 1 m, col. R. Heard, May 9, 2001 (5).

Diagnosis: Bidentate pseudospinigers are present and there are about 10 falcigers in anterior parapodia. The bidentate falcigers have long spines reaching to the level of the proximal tooth. Two curved and acuminate acicula are present in anterior parapodia with 1 acicula per parapodium in the remainder of the body. The simple setae in the posterior were bidentate. Dorsal cirri in the mid-body have about 25 segments.

Distribution: This species was described from Northwestern Australia but has also been reported from Cuba and Venezuela in the Caribbean (Dean, 2012). Granados-Barba, SolísWeiss, Tovar-Hernández and Ochoa-Rivera (2003) also reported this species from Caribbean Mexico and the Mexican Gulf of Mexico.

\section{Syllis corallicola \\ Verrill, 1900}

Material examined: Portete, coralline rock, $10^{\circ} 00^{\prime} 35.91^{\prime \prime} \mathrm{N}-83^{\circ} 03^{\prime} 17.43^{\prime}$ "W June 30, 1994 (1).

Diagnosis: The compound bidentate falcigers have teeth of similar size and 4 aciculae occur in anterior setigers. Dorsal cirri were few but those present had about forty segments. 
Distribution: This species has a widespread distribution and is known from the Mediterranean, the Gulf of Mexico and the Pacific Ocean. In the Caribbean it has been reported at many sites from the Barbados to Cuba (Dean, 2012).

\section{Syllis garciai \\ (Campoy, 1982)}

Material examined: Puerto Vargas, rock wash, $1 \mathrm{~m}$, col. R. Heard, May 9, 2001 (1 MZUCR-373-09). Manzanillo, coral reef (taken while snorkeling), 9³8'12.86" N-82'39'15.90" W, Aug. 21, 2006 (1).

Diagnosis: Bidentate pseudospinigers are present and there are 3 aciculae per parapodium including a needle-like acicula. Simple setae in the far posterior are bidentate. Dorsal cirri alternate in length with $8-10$ and 10-12 segments in the mid-body.

Distribution: This species was described from the Spanish Mediterranean and has also been reported from Cuba and Venezuela in the Caribbean (Dean, 2012).

\section{Syllis lutea \\ (Hartmann-Schroeder, 1960)}

Material examined: Puerto Vargas, rock wash, 1 m, col. R. Heard, May 9, 2001 (3). Puerto Vargas, rock wash, $1 \mathrm{~m}$, col. R. Heard, Oct. 9, 2001 (7 MZUCR-375-01).

Diagnosis: Bidentate falcigers are present with about twelve falcigers and 2 aciculae per parapodium throughout. Dorsal cirri alternate with about forty and eighteen segments throughout.

Distribution: This species was described from the Red Sea and is considered circumtropical (Licher, 1999). It has been reported from Cuba and Venezuela in the Caribbean (Dean, 2012).

\section{Trypanosyllis vittigera Ehlers, 1887}

Material examined: Puerto Vargas, rock wash, 1m, col. R. Heard, May 9, 2001 (1 MZUCR-373-03).
Diagnosis: The trepan has 10 small teeth and the proventriculus is longer than the pharynx tube. Mid-body segments with dorsal cirri of about seventy segments. Transverse pigment stripes on the anterior dorsum.

Distribution: Liñero-Arana and DíazDíaz (2011) reported this species from Caribbean Venezuela and regard this species as being circumtropical.

\section{Family Terebellidae Johnston, 1846 Amphitritides bruneocomata} (Ehlers, 1887)

Material examined: Cahuita, seagrass and coralline rock, 9०44'47.22" N-8248'37.49" W, Aug. 22, 2006 (1).

Diagnosis: There are 2 pairs of shortstalked dendritic branchiae and thoracic uncini are in double, facing rows. Lateral lappets are absent and there are sixteen ventral shields. Notosetae are present from setiger 4 to 31 ; notosetae are either long and denticulate with a bilimbate proximal region, or shorter with denticulations but lacking limbations. Nephridial papillae are present from setiger 3, then from setigers 6 to 19 as described for this species by Londoño-Mesa (2009).

Distribution: Amphitritides bruneocoma$t a$ is known from Southern Florida, the Gulf of Mexico, the Mexican Caribbean, Puerto Rico and Venezuela (Londoño-Mesa, 2009; Dean, 2012). Presently this is the only known species in this genus in the Caribbean Sea (LondoñoMesa, 2009).

\section{Eupolymnia magnifica \\ (Webster, 1884)}

Material examined: Manzanillo, intertidal beach rock, off reef, 9038'16.33" N-82³9'14.37' W, Aug. 28, 2009 (1).

Diagnosis: Three pairs of branched branchiae occur on segments 2-4 and there are seventeen thoracic setigers. Lateral lappets are very short and inconspicuous and eyespots are lacking. Notosetae first occur of segment 4 and neuropodial uncini on segment 5 . Uncini have 
an elongate subrostrum and 2 teeth above the main fang. The first 6 thoracic setigers have a single row of uncini.

Distribution: This species was described from Bermuda and has been reported from Antigua in the Caribbean (Treadwell, 1924). Londoño-Mesa (2009) has also reported it from the Bahamas, Gulf of Mexico, Cuba, Caribbean Mexico, Puerto Rico, Panama and Curaçao.

\section{Eupolymnia rullieri}

Londoño-Mesa, 2009

Material examined: Puerto Vargas, rock wash, 1m, col. R. Heard, May 9, 2001 (7). Manzanillo, intertidal beach rock, off reef, 9038'16.33" N-82³9'14.37” W, Aug. 28, 2009 (1).

Diagnosis: Three pairs of branchiae are present and there are seventeen thoracic setigers. Small lateral lappets are present on segments 2 and 3 as well as a small, inconspicuous lappet on segment 4 . This species is most easily distinguished from E. magnifica by having only the first 5 thoracic setigers with a single row of uncini (unique to the genus) and a band of eyespots on the prostomium.

Distribution: Londoño-Mesa (2009) described this species from the Mexican Caribbean but also reported it in Puerto Rico, Guadeloupe, St. Vincent and Panama in the Caribbean as well as in the Gulf of Mexico.

\section{Lanicola carus \\ (Young \& Kritzler, 1987)}

Material examined: Cahuita Point, broken rock, 944'24.89' N-8250'35.93' W, May 14, 2011 (3). Manzanillo, intertidal beach rock, off reef, 9³8'16.33" N-82³9'14.37' W, Aug. 28, 2009 (1).Manzanillo, coral reef (taken while snorkeling), 9³8'12.86" N-82³9'15.90" W, Aug. 21, 2006(1). Puerto Vargas, rock wash, $1 \mathrm{~m}$, col. R. Heard, May 9, 2001 (13 MZUCR-373-08). Limón, beach wall, rocky intertidal, 9'59'39.01" N-82 48'37.49” W, June 30, 1994 (1).
Diagnosis: There are 2 pairs of dendritic branchiae and a large lateral lappet attached to segment 2 ventrally and 3 dorsally. There are seventeen thoracic setigers and the uncini are in double rows in the thorax (except first few setigers). As described for the species by Londoño-Mesa (2009) nephridial papillae occur on setigers 3,4 and 6 and 7. There are lateral fields of closely spaced eyespots on smaller individuals but these are absent in larger specimens. Londoño-Mesa (2009) states that these eyespots were lacking on some of his specimens from the Caribbean.

Distribution: Londoño-Mesa (2009) reported Lanicola carus from Florida in the Gulf of Mexico and from numerous sites in the Caribbean from Mexico to Venezuela, Bonaire, Curaçao, Grenada, and Tortuga including the type locality, Belize. He also reported an occurrence from Pacific Panama in the Eastern Tropical Pacific.

\section{Loimia minuta}

Treadwell, 1929

Material examined: Manzanillo, coral reef (taken while snorkeling), 9'38'12.86" N-82³9'15.90” W, Aug. 21, 2006 (1).

Diagnosis: Three small dendritic branchiae are present and there are seventeen thoracic setigers. There is a large lateral lappet on segment 1 and a smaller lappet on the posterior of segment 3 . The single row of teeth on the uncini is characteristic of the genus and there were 4 equal sized teeth. Notosetae were of 2 types; long and bilimbate, and slightly shorter without limbations.

Distribution: Londoño-Mesa (2009) redescribed L. minuta, originally described from the Florida Keys, and reported it from the Mexican Caribbean. It is likely that many reports of $L$. medusa (Savigny in Lamarck, 1818) from the Caribbean may include this species (as well as perhaps other reported species of Loimia). As pointed out by Hutchings and Glasby (1995), this "cosmopolitan" species is probably a complex of morphologically similar species. 
Londoño-Mesa (2009) indicated that a revision of the genus is currently underway.

\section{Pista palmata \\ (Verrill, 1873)}

Material examined: Limón, seagrass and broken rock, 9'44'47.22" N-82'48'37.49" W, Aug. 22, 2006 (1).

Diagnosis: This has 2 pairs of dendritically branched branchiae and smooth notosetae. The uncini in the first setiger has a long posterior process while this process is lacking in uncini from more posterior thoracic setigers. Segment 4 has dorsal lobes which are adjacent to each other.

Distribution: This species was described from Connecticut (USA) in the Western North Atlantic and Londoño-Mesa (2009) reported it from the Gulf of Mexico, and Mexico and Panama in the Caribbean. It has also been reported several times from Caribbean Colombia (in Dean, 2012).

\section{Streblosoma hartmanae} Kritzler, 1971

Material examined: Manzanillo, coral reef (taken while snorkeling), 9'38'12.86" N-82³9'15.90” W, Aug. 21, 2006 (1).

Diagnosis: The thoracic notosetae are denticulate and the uncini are in a single row. The first notosetae occur on segment 2 . There are 3 pairs of filiform branchiae; the first pair with 4 or 5 , the second pair with 3 or 4 , and the 3 rd pair with 3 filiform branchiae. The first pair of branchiae emerges anterior to, rather than dorsal to, the notopodia.

Distribution: Londoño-Mesa (2009) reported this species to occur in Georgia and Florida in the Gulf of Mexico, and Mexico, Panama, Aruba, Bonaire, and Curaçao in the Caribbean. He also has identified this species from the Pacific side of Panama.

\section{DISCUSSION}

Sixty eight polychaete species were identified with the Syllidae (12 species) and the
Eunicidae (11 species) being the most species rich families. The families Polynoidae and Sabellidae were also species rich with six species occurring in each family. While sampling was not quantitative, the highest numbers of specimens collected were the Nereididae Perinereis sp. and Platynereis dumerilii, the Eunicidae Eunice bucciensis, and the Chaetopteridae Mesochaetopterus capensis.

Sixty six species are newly reported for Caribbean Costa Rica with 2, Hemipodia pustatulus and Palola siciliensis having been previously recorded. When compared to Caribbean Panama, with 200 reported polychaete species, and Caribbean Colombia, with 268 reported species (Dean, 2012), the polychaete fauna of Caribbean Costa Rica seems low in diversity. However, poorly sampled Caribbean Nicaragua, with 1, and Honduras, with 19 reported species (Dean, 2012), illustrates that the lower number of Costa Rican species is most probably the result of reduced sample effort. This study increases the number of identified polychaete species from Caribbean Costa Rica from 9 to seventy five, greatly increasing our knowledge of the polychaete diversity of this region, and hopefully stimulating further work on this group.

\section{ACKNOWLEDGMENTS}

Travels to Costa Rica and the Caribbean coast for collecting were funded by the Centro de Investigación en Ciencias del Mar y Limnologa (CIMAR), University of Costa Rica. The collection of materials in the field was greatly aided by Jorge Cortés, Jeffrey SibajaCordero, Viktoria Bogantes, José Vargas, and Eleazar Ruiz. This paper was made much more understandable by two anonymous reviewers as well as Jorge Cortés and Jeffery SibajaCordero, both of CIMAR.

\section{RESUMEN}

Poliquetos de la zona intermareal y aguas someras de la costa del Caribe costarricense. La fauna de poliquetos en la costa del Caribe costarricense se ha descrito 
inadecuadamente con solo 9 especies reportadas anteriormente. Se estudiaron los poliquetos de de las rocas coralinas intermereales y varios sitios submareales someros en la costa del Caribe costarricense y se identificaron 68 especies, de las cuales 66 son nuevos registros para Costa Rica.

Palabras clave: Annelida, Polychaeta, mar Caribe, Costa Rica, biodiversidad marina, intermareal.

\section{REFERENCES}

Aguado, M. T., Martín, G. S., \& Hove, H. A. T. (2008). Syllidae (Annelida: Polychaeta) from Indonesia collected by the Siboga (1899-1900) and Snellius II (1984) expeditions. Zootaxa, 1673, 1-48.

Ahrens, J. B., Borda, E., Barroso, R., Paiva, P. C., Campbell, A. M., Wolf, A., Schulze, A. (2013). The curious case of Hermodice carunculata (Annelida: Amphinomidae): evidence for genetic homogeneity throughout the Atlantic Ocean and adjacent basins. Molecular Ecology, 22, 2280-2291.

Augener, H. (1906). Reports on the results of dredging, under the supervision of Alexander Agassiz, in the Gulf of Mexico and the Caribbean Sea and on the east coast of the United States, 1877 to 1880 , by the U.S. Coast Survey steamer "Blake," Lieut. Commander C. D. Sigsbee, U.S.N., and commander J. R. Bartlett, U.S.N., commanding. 42. Westindische Polychaeten. Bulletin of the Museum of Comparative Zoology, 43, 91-196.

Augener, H. (1922). Über litorale polychaeten von Westindien. Gesellschaft Naturforschender Freunde zur Berlin, 1922, 38-53.

Augener, H. (1927). Polychaeten von Curaçao. Bijdragen tot de Dierkunde, 25, 39-82.

Barroso, R., Klautau, M., Solé-Cava, A. M., \& Paiva, P. C. (2010). Eurythoe complanata (Polychaeta: Amphinomidae), the 'cosmopolitan' fireworm, consists of at least three cryptic species. Marine Biology, $157,69-80$.

Barroso, R., \& Paiva, P. C. (2007). Amphinomidae (Annelida: Polychaeta) from Rocas atoll, Northeastern Brazil. Arquivos do Museu Nacional, Rio de Janiero, 65(3), 357-362.

Bleidorn, C., \& Hausen, H. (2007). Axiothella isocirra, a new species of Maldanidae (Annelida: Polychaeta) from Belize. Proceedings of the Biological Society of Washington, 120(1), 49-55.

Böggemann, M. (2002). Revision of the Glyceridae Grube 1850 (Annelida Polychaeta). Abhandlungen der Senckenbergischen Naturforschenden Gesellschaft, $555,1-249$.
Brusa, V. S., Aguado, M. T., San Martín, G., \& Rouse, G. (2013). Revision of the genus Eusyllis Malmgren, 1867 (Annelida: Phyllodocida: Syllidae: Eusyllinae), with the description of a new species from the eastern Pacific Ocean. Zootaxa, 3599(1), 37-50.

Budaeva, N., \& Fauchald, K. (2008). Diopatra tuberculantennata, a new species of Onuphidae (Polychaeta) from Belize with a key to onuphids from the Caribbean Sea. Zootaxa, 1795, 29-45.

Carrera-Parra, L. F. (2009). Oenonidae Kinberg, 1865. In J. A. De León-González, J. R. Bastida-Zavala, L. F. Carrera-Parva, M. E. García-Garza, A. Peña-Rivera, S. I. Salazar Vallejo, \& V. Solís-Weiss (Eds.), Poliquetos (Annelida: Polychaeta) de Mexico y America Tropical (Vol. II, pp. 355-362).

Carrera-Parra, L. F., Fauchald, K., \& Gambi, M. C. (2011). Revision of the taxonomic status of Lysidice (Polycaheta, Eunicidae) in the Western Caribbean Sea with observation on species reproductive features and habitat preference. Italian Journal of Zoology, $78(\mathrm{~S} 1), 27-40$.

Carrera-Parra, L. F., \& Salazar-Vallejo, S. I. (1998). Eunícidos (Polychaeta) del Caribe mexicano con claves para las especies del Gran Caribe: Eunice. Revista de Biologia Tropical, 45, 1499-1521.

Cinar, M. E. (2007). Re-description of Timarete punctata (Polychaeta: Cirratulidae) and its occurrence in the Mediterranean Sea. Scientia Marina, 71(4), 755-764.

Çinar, M. E. (2009). Alien polychaete species (Annelida: Polychaeta) on the southern coast of Turkey (Levantine Sea, eastern Mediterranean), with 13 new records for the Mediterranean Sea. Journal of Natural History, 43 (37-38), 2283-2328.

Colbath, G. K. (1989). A revision of Arabella mutans (Chamberlin, 1919) and related species (Polychaeta: Arabellidae). Proceedings of the Biological Society of Washington, 102(2), 283-299.

Cortés, J., \& Wehrtmann, I. S. (2009). Diversity of Marine Habitats of the Caribbean and Pacific of Costa Rica. In I. S. Wehrtmann, \& J. Cortés (Eds.), Marine Biodiversity of Costa Rica, Central America (pp. 1-45). Springer Science + Business Media B. V.

Cosentino, A., \& Giacobbe, S. (2011). The new potential invader Linopherus canariensis (Polychaeta: Amphinomidae) in a Mediterranean coastal lake: Colonization dynamics and morphological remarks. Marine Pollution Bulletin, 62(2), 236-245.

de Assis, J. E., Alonso, C., de Brito, R. J., Dos Santos, A. S., \& Christoffersen, M. L. (2012). Polychaetous annelids from the coast of Paraíba State, Brazil. Revista Nordestina de Biologia, 21(1), 3-45.

de León-González, J. A. (2009). Nereididae Lamarck, 1818. In J. A. De León-González, J. R. Bastida-Zavala, L. F. 
Carrera-Parva, M. E. García-Garza, A. Peña-Rivera, S. I. Salazar Vallejo, \& V. Solís-Weiss (Eds.), Poliquetos (Annelida: Polychaeta) de Mexico y America Tropical (Vol. II, pp. 325-354).

de León-González, J. A., \& Diaz-Castañeda, V. (2006). Eunicidae (Annelida: Polychaeta) associated with Phragmathopoma caudata Morch, 1863 and some coral reefs from Veracruz, Gulf of Mexico. Scientia Marina, 70S3, 91-99.

de León-González, J. A., \& Solís-Weiss, V. (1998). The genus Perinereis (Polychaeta: Nereididae) from Mexican littoral waters, including the description of three new species and the redescriptions of $P$. anderssoni and P. elenacasoae. Proceedings of the Biological Society of Washington, 111(3), 674-693.

de León-González, J. A., Solís-Weiss, V., \& Ochoa-Rivera, V. (1999). Nereidids (Polychaeta) from the Caribbean Sea and adjacent Coral Islands of the southern Gulf of Mexico. Proceedings of the Biological Society of Washington, 112(4), 667-681.

de León-González, J. A., Solís-Weiss, V., \& ValadezRocha, V. (2001). Two new species of Platynereis (Polychaeta: Nereididae) from eastern Mexican shores. Proceedings of the Biological Society of Washington, 114(2), 389-395.

Dean, H. K. (2009). Polychaetes and Echiurans. In I. S. Wehrtmann \& J. Cortés (Eds.), Marine Diversity of Costa Rica, Central America (pp. 181-191). Springer Science + Business Media B. V.

Dean, H. K. (2012). A literature review of the Polychaeta of the Caribbean Sea. Zootaxa, 3596, 1-86.

Dos Santos, A. S., Riul, P., Santos, B., Brasil, A. C. D. S., \& Christoffersen, M. L. (2011). Encrusting Sabellariidae (Annelida: Polychaeta) in rhodolith beds, with description of a new species of Sabellaria from the Brazilian coast. Journal of the Marine Biological Association of the United Kingdom, 91(2), 425-438.

Ehlers, E. (1887). Report on the annelids 31. Memoirs of the Museum of Comparative Zoology at Harvard College, 15, 1-335.

Fauchald, K. (1973). Polychaetes from Central American sandy beaches. Bulletin of the Southern California Academy of Sciences, 72, 19-31.

Fauchald, K. (1992). A review of the genus Eunice (Polychaeta: Eunicidae) based upon type material. Smithsonian Contributions to Zoology, 523, 1-422.

Fauchald, K., Granados Barba, A., \& Solís-Weiss, V. (2009). Polychaeta (Annelida) of the Gulf of Mexico. In D. L. Felder, \& D. K. Camp (Eds.), Gulf of Mexico origin, waters, and biota (Vol. I, pp. 751-788). College Station, Texas: Texas A\&M University Press.
Fukuda, M. V., \& Nogueira, J. M. M. (2006). A new species of Odontosyllis Claparáde, 1863 (Polychaeta: Syllidae: Eusyllinae), and description of Brazilian material of Odontosyllis cf. fulgurans (Audouin and Milne Edwards, 1834). Zoological Studies, 45(2), 223-233.

Gardiner, S. L. (1976). Errant polychaete annelids from North Carolina. Journal of the Elisha Mitchell Scientific Society, 91(3), 77-220.

Giangrande, A., Licciano, M., \& Gambi, M. C. (2007). A collection of Sabellidae (Polychaeta) from Carrie Bow Cay (Belize, western Caribbean Sea) with the description of two new species. Zootaxa, 1650, 41-53.

Gillet, P. (1989). Axiothella crozetensis, a new species of Maldanid polychaete from Crozet Islands (Indian Ocean). Proceedings of the Biological Society of Washington, 102(4), 866-871.

Glockner-Fagetti, A. (2009). Chaetopteridae Audouin \& Milne Edwards, 1833. In J. A. De León-González, J. R. Bastida-Zavala, L. F. Carrera-Parva, M. E. García-Garza, A. Peña-Rivera, S. I. Salazar Vallejo \& V. Solís-Weiss (Eds.), Poliquetos (Annelida: Polychaeta) de Mexico y America Tropical (Vol. I, pp. 115-121).

Granados-Barba, A., Solís-Weiss, V., Tovar-Hernández, M. A., \& Ochoa-Rivera, V. (2003). Distribution and diversity of the Syllidae (Annelida: Polychaeta) from the Mexican Gulf of Mexico and Caribbean. Hydrobiologia, 496, 337-345.

Habib, F., \& Mustaquim, J. (1988). New records of polychaete annelids from coastal waters of Pakistan. Pakistan Journal of Zoology, 20(3), 304-306.

Hartman, O. (1965). Catalogue of the polychaetous annelids of the world. Supplement 1960-1965. Allen Hancock Foundation Occasional Paper, 23, 1-197.

Hutchings, P., \& Glasby, C. J. (1995). Description of the widely reported terebellid polychaetes Loimia medusa (Savigny) and Amphitrite rubra (Risso). Mitteilungen aus dem Hamburgischen Zoologischen Museum und Institut, 92, 149-154.

Ibarzábal, D. R. (1986). Lista de especies de poliquetos bentónicos cubanos. Reporte de Investigación del Instituto de Oceanologia, 45, 1-17.

Jiménez-Cueto, M. S., \& Salazar-Vallejo, S. I. (1997). Maldánidos (Polychaeta) del Caribe Mexicano con una clave para las especies del Gran Caribe. Revista de Biologia Tropical, 45, 1459-1480.

Knight-Jones, P., \& Perkins, T. H. (1998). A revision of Sabella, Bispira and Stylomma (Polychaeta: Sabellidae). Zoological Journal of the Linnean Society, 123, 385-467. 
Lana, P. C. (1984). Anelídeos poliquetas errantes do litoral do estado do Paraná (Tese de Doutorado). Universidade de São Paulo, Brazil.

Lattig, P., \& Martin, D. (2011). Sponge-associated Haplosyllis (Polychaeta: Syllidae: Syllinae) from the Caribbean Sea, with the description of four new species. Scientia Marina, 75(4), 733-758.

Licher, F. (1999). Revision der gattung Typosyllis Langerhans, 1879 (Polychaeta: Syllidae). Abhandlungen der senckenbergischen naturforschenden Gesellschaft, $551,1-336$

Liñero Arana, I. (2013). Nuevos registros de sabellariidae (Annelida: Polychaeta) para el Mar Caribe. Interciencia, 38(5), 382-386.

Liñero Arana, I., \& Díaz-Díaz, Ó. (2011). Syllidae (Annelida, Polychaeta) from the Caribbean coast of Venezuela. Zookeys, 117, 1-28.

Londoño-Mesa, M. H. (2009). Terebellidae (Polychaeta: Terebellida) from the Grand Caribbean region. Zootaxa, 2320, 1-93.

López, E., Capa, M., Aguado, M. T., \& Cladera, P. (2005). Capitellidae (Annelida: Polychaeta) from Coiba National Park, Pacific coast of Panamá, with a new species of the genus Amastigos. Cahiers de Biologie Marine, 46, 57-67.

Maciolek, N. J. (1985). A revision of the genus Prionospio Malmgren, with special emphasis on species from the Atlantic Ocean, and new records of species belonging to the genera Apoprionospio Foster and Paraprionospio Caullery (Polychaeta, Annelida, Spionidae). Zoological Journal of the Linnean Society, 84, 325-383.

Maltagliati, F., Massaro, L., Cossu, P., \& Castelli, A. (2006). Morphological differentiation in the ragworm, Hediste diversicolor (Polychaeta, Nereididae), as revealed by variation of paragnath number and distribution. Italian Journal of Zoology, 73(3), 255-262.

Magalhães, W. F., Seixas, V. C., Paiva, P. C., \& Elias, R. (2014) The Multitentaculate Cirratulidae of the Genera Cirriformia and Timarete (Annelida: Polychaeta) from Shallow Waters of Brazil. PLoS ONE, 9(11): e112727. doi:10.1371/journal.pone.0112727

Miloslavich, P., Díaz, J. M., Klein, E., Alvarado, J. J., Díaz, C., Gobin, J., ... \& Ortiz, M. (2010). Marine Biodiversity in the Caribbean: Regional Estimates and Distribution Patterns. PLoS ONE, 5(8): e11916. doi:10.1371/journal.pone.0011916

Mora-Vallín, Z. G. (2009). Chrysopetalidae Ehlers, 1864. In J. A. De León-González, J. R. Bastida-Zavala, L. F. Carrera-Parva, M. E. García-Garza, A. Peña-Rivera, S. I. Salazar Vallejo, \& V. Solís-Weiss (Eds.), Poliquetos (Annelida: Polychaeta) de México y América Tropical (Vol. I, pp. 123-129).
Paresque, K., Fukada, M. V., \& Nogueira, J. M. d. M. (2014). The genus Exogone (Polychaeta: Syllidae) from the Brazilian coast, with the description of a new species. Zootaxa, 3790, 501-533.

Pepe, P. J. (1985). Littoral endolithic fauna of the Central American Isthmus. Revista de Biología Tropical, 33, 191-194.

Perkins, T. H. (1979). Lumbrineridae, Arabellidae, and Dorvilleidae (Polychaeta), principally from Florida, with descriptions of six new species. Proceedings of the Biological Society of Washington, 92(3), 415-465.

Perkins, T. H. (1980). Review of species previously referred to Ceratonereis mirabilis, and descriptions of new species of Ceratonereis, Nephtys, and Goniada (Polychaeta). Proceedings of the Biological Society of Washington, 93(1), 1-49.

Perkins, T. H. (1984). Revision of Demonax Kinberg, Hypsicomus Grube, and Notaulax Tauber, with a review of Megalomma Johansson from Florida (Polychaeta: Sabellidae). Proceedings of the Biological Society of Washington, 97(2), 285-368.

Perkins, T. H. (1985). Chrysopetalum, Bhawania and two new genera of Chrysopetalidae (Polychaeta), principally from Florida. Proceedings of the Biological Society of Washington, 98(4), 856-915.

Pettibone, M. H. (1956). Some polychaete worms of the families Hesionidae, Syllidae, and Nereidae from the east coast of North America, West Indies, and Gulf of Mexico. Journal of the Washington Academy of Sciences, 46(9), 281-294.

Pettibone, M. H. (1963). Marine polychaete worms of the New England region. I. Aphroditidae through Trochochaetidae. Bulletin of the United States National Museum, 227(1), 1-356.

Pettibone, M. H. (1971). Partial revision of the genus Sthenelais Kinberg (Polychaeta: Sigalionidae) with diagnoses of two new genera. Smithsonian Contributions to Zoology, 109, 1-40.

Pettibone, M. H. (1975). Review of the genus Hermenia, with a description of a new species (Polychaeta: Polynoidae: Lepidonotinae). Proceedings of the Biological Society of Washington, 88(22), 233-248.

Purschke, G., Ding, Z., \& Müller, M. C. (1995). Uitrastructural differences as a taxonomic marker: the segmental ocelli of Polyophthalmus pictus and Polyophthalmus qingdaoensis sp.n. (Polychaeta, Opheliidae). Zoomorphology, 115, 229-241.

Salazar-Silva, P. (2010). Redescription of Harmothoe crucis (Annelida, Polychaeta, Polynoidae), and re-establishment of synonymized species from the Grand Caribbean with descriptions of four new species. Marine Biology Research, 6, 125-154. 
Salazar-Silva, P. (2013). Revision of Halosydna Kinberg, (Annelida: Polychaeta: Polynoidae) from the Tropical Eastern Pacific and Grand Caribbean with descriptions of new species. Journal of Natural History, 47(17-18), 1177-1242.

Salazar-Vallejo, S. I. (2003). Revision of Synelmis Chamberlin, 1919 (Annelida, Polychaeta, Pilargidae). Zoosystema, 25, 17-41.

Salazar-Vallejo, S. I. (2012). Revision of Semiodera Chamberlin, 1919 (Polychaeta: Flabelligeridae). Zootaxa, $3562,1-62$.

Salazar-Vallejo, S. I., \& Carrera-Parra, L. F. (1997). Eunícidos (Polychaeta) del Caribe mexicano con claves para las especies del Gran Caribe: Fauchaldius, Lysidice, Marphysa Nematonereis y Palola. Revista de Biología Tropical, 45, 1481-1498.

San Martín, G. (1991). Grubeosyllis and Exogone (Exogoninae, Syllidae, Polychaeta) from Cuba, the Gulf of Mexico, Florida and Puerto Rico, with a revision of Exogone. Bulletin of Marine Science, 49, 715-740.

San Martín, G., Aguirre, O., \& Baratech, L. (1986). Anélidos poliquetos procedentes de la I expedición Cubano-Espanola a la Isla de la Juventud y Archipiélago de los Canarreos I. Familias Polynoidae, Sigalionidae, Pholoididae y Pisionidae. Revista de Investigaciones Marinas, 7(1), 3-16.

San Martín, G., \& Bone, D. (2001). Syllidae (Polychaeta) de praderas de Thalassia testudinum en el Parque Nacional Morrocoy (Venezuela). Revista de Biología Tropical, 49(2), 609-620.

Schulze, A. (2006). Phylogeny and genetic diversity of Palolo worms (Palola, Eunicidae) from the tropical North Pacific and the Caribbean. Biological Bulletin, 210, 25037.

Schulze, A., \& Timm, L. E. (2012). Palolo and un: distinct clades in the genus Palola (Eunicidae, Polychaeta). Marine Biodiversity, 42, 161-171.
Sheridan, P. (1997). Benthos of Adjacent Mangrove, Seagrass and Non-vegetated Habitats in Rookery Bay, Florida, U.S.A. Estuarine and Coastal Shelf Science, 44, 455-469.

Taylor, J. L. (1984). Chapter 31. Family Neriedae Johnston, 1845. In J. M. Uebelacker, \& P. G. Johnson (Eds.), Taxonomic Guide to the Polychaetes of the Northern Gulf of Mexico (Vol. 5, pp. 31-31 to 31-42). Mobile: Barry A. Vittor \& Associates.

Tovar-Hernández, M. A., \& Carrera-Parra, L. F. (2011). Megalomma Johansson, 1925 (Polychaeta: Sabellidae) from America and other world-wide localities, and phylogenetic relationships within the genus. Zootaxa, 2861, 1-71.

Tovar-Hernández, M. A., \& Salazar-Vallejo, S. I. (2006). Sabellids (Polychaeta: Sabellidae) from the Grand Caribbean. Zoological Studies, 45(1), 24-66.

Treadwell, A. L. (1921). Leodicidae of the West Indian region. Publications of the Carnegie Institution of Washington, 15(293), 1-131.

Treadwell, A. L. (1924). Polychaetous annelids collected by the Barbados-Antigua Expedition from the University of Iowa in 1918. University of Iowa Studies in Natural History, 10(4), 3-23.

Verrill, A. E. (1900). Additions to the Turbellaria, Nemertina, and Annelida of the Bermudas, with revisions of some New England genera and species. Transactions of the Connecticut Academy of Arts and Sciences, 10(2), 595-671.

Wehrtmann, I. S., Cortés, J., \& Echeverría-Sáenz, S. (2009). Marine Biodiversity of Costa Rica: Perspectives and Conclusions. In I. S. Wehrtmann, \& J. Cortés (Eds.), Marine Biodiversity of Costa Rica, Central America (pp. 521-533). Springer Science + Business Media B. V.

Zanol, J., Halanych, K. M., \& Fauchald, K. (2014). Reconciling taxonomy and phylogeny in the bristleworm family Eunicidae (polychaete, Annelida). Zoologica Scripta, 43, 79-100. 